\title{
Perceived Usage of E-Wallet among the Y Generation in Surabaya Based on Technology Acceptance Model
}

\author{
Dewi Pertiwi ${ }^{* *}$, Widjojo Suprapto ${ }^{1}$, Eric Pratama ${ }^{1}$
}

\begin{abstract}
Although the government of Indonesia is building the cashless society, the number of e-wallet users are increasing slowly. E-wallet is becoming a common instrument of payments, to replace the paper-based instruments to server-based electronic money. This research aims to investigate the perceived usage of the Y Generations on e-wallet based on Technological Acceptance Model (TAM) which is a powerful model to describe single approval to the usage of a new information technology system. As a quantitative research, the data analysis is using the Partial Least Square (PLS) with the SmartPLS 3.0 software. The results show that perceived usefulness and perceived ease of use have significant positive impacts on behavioural intention to use. The behavioural intention to use brings a significant positive impact on perceived usage. However, a direct result from perceived usefulness to perceived usage shows a negative and no significant impact, meanwhile an unintended consequence from perceived usefulness to perceived usage through behavioural intention to use shows a significant positive impact. Finally, a direct effect from perceived ease of use to perceived usage shows a lower $t$-statistic value than an indirect effect from perceived ease of use to perceived usage through behavioural intention.
\end{abstract}

Keywords: The Y generation, technological acceptance model, perceived usefulness, perceived ease of use, behavioural intention to use, perceived usage.

\section{Introduction}

Each country has a different attitude in responding to new technology, one of which is Indonesia. As the fourth most populous country in the world, the market in Indonesia has an excellent opportunity for the development of the digital economy. Yet, as one of the emerging market countries in Asia, the government of Indonesia still needs to intervene to create a cashless society. The cashless society creation is proved by the seriousness of Bank Indonesia in accelerating the electronification of non-cash payments in various sectors. One of the policies undertaken is the imposition of non-cash payments in all existing toll highways. In other sectors, the electronification program is also expanded within the local government to support the effectiveness of the management of state finances through transparency and more efficient cash management [1]. Non-cash transactions are increasingly prevalent with the presence of e-commerce in Indonesia, such as Tokopedia, Shopee, Bukalapak, etc. The non-cash transactions have led to changes in marketing strategies at various stores from offline to online. The development of e-commerce has been responded positively by financial technology (fintech),

${ }^{1}$ Faculty of Business and Economics, Department of Management, Petra Christian University, Лl. Siwalankerto 121-131, Surabaya, Indonesia 60236

Email: dewi.pertiwi@petra.ac.id, joe.suprapto@gmail.com, ericpratamaaa@gmail.com

* Corresponding author a company that provides electronic wallet services (ewallet) such as Gopay, OVO, LinkAja and Dana. The e-wallet changes the concept that money stored in a leather wallet into deposited in a digital wallet inside the smartphone. Generally, fintech companies carry out a "burn money" strategy by providing attractive promotions in the form of cashbacks from various restaurants and merchants. The e-wallet has changed the payment tools for Indonesian society. The data from Bank Indonesia shows a significant increase in the amount of electronic money circulations, from 21.869.946 in 2012 to 292.299.320 in December 2019 [2]. The average age of the population who dominates the growth of E-wallet users in Indonesia is of 30.5 years old [3].

In 2020, these 30-year-old users are considered as the Y generation or millenial generation as they were born between the period of 1981 to 1999. Data from the Central Statistics Agency (BPS) show that the population of the Indonesian Y generation in 2020 will be 83 millions or $34 \%$ of the Indonesia's total population. The $\mathrm{Y}$ generation has the most notable influence in Indonesian businesses (at least for the next ten years), since most of the $\mathrm{Y}$ generation is in the productive age [4]. Most of the Y generation were born from parents with solid financial backgrounds and are prepared in a contextually wealthy environment [5].

The $\mathrm{Y}$ generation is also dominating the population of Surabaya, the capital city of East Java, with the largest number of electronic money users in East Java 
[6]. For the Y generation, smartphones have become an essential part of their lives. Smartphones are not only a tool to communicate (telephone and chat) but are also used to access various information and online transactions. A study in a developing country by Cheng et al. [7] showed that $98 \%$ of the Y generation respondents had used smartphones, but only $50 \%$ of respondents had used e-wallets, because most respondents still preferred cash payments to e-wallets.

This study will investigate the use of e-wallet as a transaction payment tool for the $\mathrm{Y}$ generation in Surabaya based on the framework of Technology Acceptance Model (TAM), where this model is widely used to analyze the acceptance of new technological innovation. TAM explained by Davis [8], is the most popular and influential model to describe the single reception of the use of information technology systems. TAM is used to measure information technology adoption, and it is known to be very robust theoretically and very beneficial for the identification of the reasons for user's new technology acceptance [9]. The previous researchers have persisted that TAM is a legitimate model that reflects a crucial theoretical framework for clarifying and predicting technology acceptance behavior [10]. TAM uses two fundamental beliefs in determining attitudes toward technology and actual acceptance, both of which are: perceived usefulness (PU) and perceived ease of use (PEU). PU considers that technology will be used when it can improve performance. In his article, Davis [8] defines PU as a belief that drives decision making. PU fundamentally refers to acting the work more efficiently and effectively as well as reducing the time for finishing the job. The number of users involved in using technology is determined from the extent to which technology can maximize users' performance [11]. Additionally, PEU assesses that technology will be adopted when it is less hussle of efforts in using it [12]. Davis [8] defines PEU as a person's belief in the comfort of using a system.

The primary dependent variable in developing the study of TAM is a behavioral intention to use (BIU) [8]. Referring to the behavioral intention theory of previous researchers, an individual's BIU towards ewallet is determined by two things, namely: an individual's attitude towards the use of e-wallet and subjective norms [13]. Behavioral attitude refers to advantages and disadvantages when using e-wallet. Subjective norms refer to the use of e-wallets because of the influence of others. According to TAM, user's behavior in technology usage is determined by the intention, which is affected by the PU and the PEU. $\mathrm{PU}$ is shown to have a very strong influence over BIU [14]. This result confirms findings in previous studies explaining that PU is one of the factors influencing the intention to use payment services with smartphones [15]. PU of a specific technology will cause an individual to plan using the technology. As a crucial variable, perceived value can predict consumer acceptance and continual willingness for an e-wallet. PU greatly influences the acceptance of WeChat payments [16]. This study shows the effect of perceived value in using e-wallet as the intended payment tools for generation Y. So, the hypothesis can be constructed as follows:

\section{H1: PU $\left(\mathrm{X}_{1}\right)$ has a positive and significant impact on $\mathrm{BIU}(\mathrm{Z})$.}

Besides PU, PEU is another variable that influences an individual acceptance of technology-based services in developing countries [17]. The result from Liu et al. [18] suggested that PEU has a significant impact over consumers' intention to use mobile payment. This study will investigate the perceived ease of use of the new technology among the $\mathrm{Y}$ generation that influences the behavioral intention to use e-wallet, especially seen from the easy e-wallet to use and the less effort in operating the system. The hypothesis is constructed as follows:

\section{$\mathrm{H} 2$ : $\mathrm{PEU}\left(\mathrm{X}_{2}\right)$ has a positive and significant impact on BIU (Z).}

PU, PEU and BIU are internal variables in TAM which are used to quantify the actual use (AU) or perceived usage of technology. On one side, BIU can be a variable predicted or assessed by PU and PEU. While on the other side, BIU is an independent variable that estimates actual usage [19]. That study is supported by Liu et al. [18] which states PU and $\mathrm{PEU}$ as two factors affecting the intention of consumer behavior in the use of technology directly. Then, BIU influences directly to the perceived usage (AU) of the system. Another study conducted by Gupta and Arora [20], inquiring users' intentions for the acceptance of mobile payment systems, shows a positive behavioral intention leading to positive use behavior toward something. From this study, it can be inferred that the higher behavioral purpose to use, the higher actual usage is. Based on the results of previous researches, this study will examine the direct and indirect impacts of $\mathrm{BIU}$ to $\mathrm{AU}$, therefore, the hypothesess are constructed as follows:

H3: BIU (Z) has a positive and significant impact on $\mathrm{AU}(\mathrm{Y})$;

$\mathrm{H} 4$ : $\mathrm{BIU}(\mathrm{Z})$ acts as a mediating variable from $\mathrm{PU}\left(\mathrm{X}_{1}\right)$ to $\mathrm{AU}(\mathrm{Y})$;

$\mathrm{H} 5$ : BIU (Z) acts as a mediating variable from PEU $\left(\mathrm{X}_{2}\right)$ to $\mathrm{AU}(\mathrm{Y})$. 


\section{Methods}

\section{Research Population and Sample}

The population for this study is those who use ewallets as a tool of payment or transactions. While the targeted population is the $\mathrm{Y}$ generation, who live in Surabaya. This research uses a nonprobability sampling technique with a purposive sampling method. This sampling method is chosen because the information is expected from a specific target group The respondents' criteria for this study are as follows:

(1) Generation Y with birth years 1980-2000. (2) Residing in the Surabaya area. (3) Have at least one ewallet account and have paid offline transactions using e-wallet at least once.

According to Hair et al. [21], the minimum standard for the number of samples is ten times the number of lines for the tested structural model. The standard sample size in the estimation model in using PLS will produce a better predictive effect. Therefore, this study will use a sample size of 10 times per indicator. The indicators used in this study are 18 indicators, so the number of respondents are at least 180 respondents.

\section{Method of Collecting Data}

Data collection technique in this study is using a questionnaire, by giving a set of written statements to respondents. The respondents will select one of the most appropriate choices for the statement written in the questionnaire. The questionnaires are distributed online, by sharing the Google Form links to selected respondents. The item statements of PU and PEU are adapted from Davis [8], meanwhile the statements of BIU variable are adapted from Kucukusta et al. [22]. The item statements for actual usage is adopted from the intensity of using e-wallet by Camilleri [14]. The measurement scale for each statement is following the Likert scale of five, from one (1) as strongly disagree to five (5) as strongly agree.

\section{Data Analysis Technique}

The analysis in this study is conducted for two purposes, namely descriptive statistic and inferential statistical analysis. Descriptive statistic explains the characteristics of respondents, especially in the assessment of research variables used in hypothesis testing. From the descriptive staatistic, this study will find the mean values that serve to clarify the scale category and facilitate the analysis of each statement. Inferential statistical analysis is used to verify the research hypothesis. This study uses smartPLS 3.0 software to process the data. The steps taken in the analysis technique include conducting a measurement model test (the outer model), conducting a structural model test (the inner model), and hypothesis and mediation testing.

\section{Results and Discussions}

\section{Descriptive Statistics Analysis of Respondents}

The research questionnaires obtained were 216 questionnaires, but 32 of them were not in accordance with established criteria, so as many as 184 questionnaires could be further processed. From the valid questionnaires, 109 respondents (59.2\%) were male, and 75 respondents (40.8\%) were female. Based on the year of birth, the respondents were grouped as follows: 19801985 (9.8\%), 1986-1990 (14.1\%), 1991-1995 (28.8\%), and 1996-2000 (27.3\%). Based on the frequency of ewallet usage for transactions during the past month, it was found that most respondents had e-wallet balance top-up frequency of 1-3 times during the past month (48.4\%). The profile of respondents based on their employment status revealed that 72 respondents were students, 109 respondents were employees, entrepreneurs, housewives, and three respondents were unemployment. The data also showed that the monthly income of most respondents was in the range of Rp. 3.500.000 - Rp. 6.000 .000 (45.1\%) and followed by an income range of less than Rp. 3.500 .000 (33.7\%).

Table 1 shows the mean value of all answers from respondents for the indicator of $\mathrm{PU}$, which is 4.399 and belongs to the category of very useful with a standard deviation of 0.703 . The result indicates that the respondents feel the usefulness of e-wallets in making payment transactions. The highest mean value of $\mathrm{PU}$ variable is 4.582 , which is the indicator of "usefulness in payment transactions". The mean value indicates that the respondents feel e-wallet very useful for doing transactions. The e-wallet users do not need to carry a large amount of cash, instead they only need to bring a smartphone with a proper balance in the e-wallet for doing transactions.

Table 2 shows the mean value obtained from respondents' answers for the PEU variable, which is 4.378 and belongs to the category of very easy to use with a standard deviation of 0.650 . The result suggests that the respondents in this study consider e-wallets as very easy to use in making payment transactions. PEU explains the extent to which an innovation is considered not difficult to understand, learn, or operate. The highest mean value of 4.554 belongs to the indicator of "ease to use". The mean value shows that the respondents find no problem in using the system.

Table 3 shows the overall mean value of BIU is 4.196 and the standard deviation is 0.770 . The BIU can be 
Table 1. Descriptive statistical analysis of $\mathrm{PU}\left(\mathrm{X}_{1}\right)$

\begin{tabular}{lcccccccrr}
\hline \multirow{2}{*}{ Indicator } & \multicolumn{4}{c}{ Answer } & \multirow{2}{*}{ Mean } & Std. & \multirow{2}{*}{ Exp. } \\
\cline { 2 - 8 } & SD & D & QA & A & SA & & Dev. & very useful \\
Transaction payment speed & 0 & 2 & 15 & 66 & 101 & 4.440 & 0.689 & very useful \\
Improved transaction payment performance & 0 & 3 & 19 & 71 & 91 & 4.359 & 0.731 & useful \\
Increased productivity of payment transactions & 0 & 5 & 29 & 83 & 67 & 4.147 & 0.777 & very useful \\
Increased effectiveness of payment transactions & 0 & 1 & 20 & 78 & 85 & 4.337 & 0.688 & very useful \\
Ease of making payment transactions & 0 & 3 & 9 & 59 & 113 & 4.527 & 0.667 & very useful \\
Use in payment transactions & 0 & 0 & 6 & 65 & 113 & 4.582 & 0.555 & very useful \\
\hline Mean and standard deviation PU & & & & & & 4.399 & 0.703 &
\end{tabular}

Table 2. Descriptive statistical analysis of PEU $\left(\mathrm{X}_{2}\right)$

\begin{tabular}{|c|c|c|c|c|c|c|c|c|}
\hline \multirow{2}{*}{ Indicator } & \multicolumn{5}{|c|}{ Answer } & \multirow{2}{*}{ Mean } & \multirow{2}{*}{$\begin{array}{l}\text { Std. } \\
\text { Dev. }\end{array}$} & \multirow{2}{*}{ Exp. } \\
\hline & SD & $\mathrm{D}$ & $\mathrm{QA}$ & $\mathrm{A}$ & $\mathrm{SA}$ & & & \\
\hline Ease of learning to operate & 0 & 1 & 5 & 85 & 93 & 4.467 & 0.580 & very easy to use \\
\hline Ease of use as desired & 0 & 2 & 17 & 87 & 78 & 4.315 & 0.683 & very easy to use \\
\hline Clarity and resolution & 0 & 0 & 17 & 92 & 75 & 4.310 & 0.631 & very easy to use \\
\hline Interaction flexibility & 0 & 2 & 29 & 77 & 75 & 4.212 & 0.783 & easy to use \\
\hline Ease of mastering & 0 & 0 & 6 & 97 & 81 & 4.408 & 0.554 & very easy to use \\
\hline Ease of use & 0 & 0 & 8 & 65 & 111 & 4.554 & 0.578 & very easy to use \\
\hline Mean and standard deviatic & & & & & & 4.378 & 0.650 & very easy to use \\
\hline
\end{tabular}

Table 3. Descriptive statistical analysis of BIU (Z)

\begin{tabular}{|c|c|c|c|c|c|c|c|c|}
\hline \multirow{2}{*}{ Indicator } & \multicolumn{5}{|c|}{ Answer } & \multirow{2}{*}{ Mean } & \multirow{2}{*}{$\begin{array}{l}\text { Std. } \\
\text { Dev. }\end{array}$} & \multirow{2}{*}{ Exp. } \\
\hline & $\mathrm{SD}$ & $\mathrm{D}$ & $\mathrm{QA}$ & $\mathrm{A}$ & $\mathrm{SA}$ & & & \\
\hline Willingness to use e-wallet in the future & 0 & 4 & 28 & 79 & 73 & 4.201 & 0.772 & high \\
\hline Willingness to regularly use e-wallet in the future & 0 & 3 & 30 & 89 & 62 & 4.141 & 0.738 & high \\
\hline Willingness to recommend to others & 1 & 2 & 29 & 71 & 81 & 4.245 & 0.794 & very high \\
\hline Mean and standard deviation BIU & & & & & & 4.196 & 0.770 & high \\
\hline
\end{tabular}

categorized has high value. The result indicates that the respondents have a high intention to use the ewallet for making payment transactions. The highest mean of 4.245 belongs to the indicator of "willingness to recommend to others." This indicates that the respondents are willing to recommend to others after they have experienced the usefulness and ease of use from e-wallet as a payment instrument.

Table 4 shows the perceived usage has an overall mean value of 3.969 , and a standard deviation of 0.859. It belongs to the high category. The result indicates that the actual use of e-wallet among the $\mathrm{Y}$ generation as payment instruments is high. However, the actual use of e-wallet can still be increased to a very high category as the main payment instrument.

\section{Partial Least Square Analysis}

For Partial Least Square (PLS) analysis, there are two steps for analysis: the outer model and the inner model. The outer model gives results for the validity and reliability tests. The validity test goes through two stages, namely convergent validity, and discriminant validity. Taherdoost [23] states that convergent validity is often used in behavioral sciences. This parameter is useful for measuring the relationship between two constructs. In this current validity test, the value of the loading factor is above the standard value of 0.7 [21] which can be observed in Table 5. Therefore, all indicators comply with the convergent validity requirement.

The second stage of the validity test is the discriminant validity. The verification of the discriminant validity can be regarded as the main part of the measurement process, if they accurately confirm the diversity between measures [24]. This test is conducted by comparing the square root of Average Variance Extracted (AVE) of a perticular construct with the other correlated constructs. In Table 6, the value of each construct is higher compared to its correlated constructs, so all variables comply with the discriminant validity requirement [21].

After validity tests, the next test is the reliability test. According to Taherdoost [23], the reliability test shows that a measurement will surrender consistant results when the research is carried out repeatedly. In PLS, the reliability test is seen from the composite reliability value and the Cronbach's alpha value.

Table 7 shows the values of the composite reliability for each variable, which are greater than 0.7 , and the values of Cronbach's alpha, which are greater than 0.6. According to Hair et al. [21], a research can be said 
Table 4. Descriptive statistical analysis of AU (Y)

\begin{tabular}{lcccccccc}
\hline \multirow{2}{*}{ Indicator } & \multicolumn{4}{c}{ Answer } & \multirow{2}{*}{ Mean } & Std. & \multirow{2}{*}{ Exp. } \\
\cline { 2 - 7 } & SD & D & QA & A & SA & & & Dev. \\
\hline The intensity of checking e-wallet balances & 2 & 10 & 45 & 83 & 44 & 3.859 & 0.879 & high \\
The intensity of top-up e-wallet balances & 2 & 6 & 28 & 100 & 48 & 4.011 & 0.801 & high \\
The intensity of payment transactions using e-wallet & 2 & 8 & 31 & 82 & 61 & 4.038 & 0.881 & high \\
\hline Mean and Standard Deviation AU & & & & & & 3.969 & 0.859 & high \\
\hline
\end{tabular}

Table 5 Convergent validity

\begin{tabular}{|c|c|c|c|c|}
\hline Indicator & $\begin{array}{l}\text { Perceived usefulness } \\
\left(\mathrm{X}_{1}\right)\end{array}$ & $\begin{array}{l}\text { Perceived ease of use } \\
\left(\mathrm{X}_{2}\right)\end{array}$ & $\begin{array}{l}\text { Behavioral intention to use } \\
\text { (Z) }\end{array}$ & $\begin{array}{l}\text { Perceived usage } \\
\text { (Y) }\end{array}$ \\
\hline PU1 & 0.767 & & & \\
\hline PU2 & 0.745 & & & \\
\hline PU3 & 0.760 & & & \\
\hline PU4 & 0.798 & & & \\
\hline PU5 & 0.747 & & & \\
\hline PU6 & 0.730 & & & \\
\hline PEU1 & & 0.770 & & \\
\hline PEU2 & & 0.801 & & \\
\hline PEU3 & & 0.782 & & \\
\hline PEU4 & & 0.713 & & \\
\hline PEU5 & & 0.744 & & \\
\hline PEU6 & & 0.779 & & \\
\hline BIU1 & & & 0.911 & \\
\hline BIU2 & & & 0.917 & \\
\hline BIU3 & & & 0.818 & \\
\hline AU1 & & & & 0.812 \\
\hline AU2 & & & & 0.911 \\
\hline AU3 & & & & 0.852 \\
\hline
\end{tabular}

Table 6. Discriminant Validity

\begin{tabular}{lcccc}
\hline \multicolumn{1}{c}{ Variable } & $\begin{array}{c}\text { Perceived } \\
\text { usefulness }\end{array}$ & Perceived ease of use & Perceived usage & $\begin{array}{c}\text { Behavioral intention to } \\
\text { use }\end{array}$ \\
\hline Perceived Usefulness & 0.758 & & & \\
Perceived Ease of Use & 0.605 & 0.765 & 0.859 & 0.883 \\
Perceived Usage & 0.406 & 0.487 & 0.59 & 0.542 \\
Behavioral Intention to Use & 0.582 & & & \\
\hline
\end{tabular}

as reliable, if the composite reliability value is greater than or equal to 0.7 . Therefore, all variables fulfill the requirement for the composite reliability.

Finally, the inner model gives the result for the coefficient of determination $\left(R^{2}\right)$. The value of $\mathrm{R}^{2}$ is used to quantify the level of variation in the changes of the independent variable to the dependent variable. $R^{2}$ is used as a measure of the explanatory power of the model [21]. High $\mathrm{R}^{2}$ values are needed for better predictions of users' behavior, perceptions and intentions. The $\mathrm{R}^{2}$ values of this study indicate that $\mathrm{PU}$ and PEU influence BIU of 0.395 or $39.5 \%$, while PU, PEU, and BIU influence AU of 0.388 or $38.8 \%$.

\section{Result of the Hypothesis Test}

Table 9 resumes the results of the hypothesis testing performance of this study. When the value of the t-statistic is greater than 1.96, the hypothesis is accepted.
The first hypothesis, which states perceived usefulness $\left(\mathrm{X}_{1}\right)$ having a positive and significant impact on $\mathrm{BIU}(\mathrm{Z})$, is accepted as the T-statistic shows the value of 4.383 , greater than 1.96 . This study confirms that the intention to use e-wallet as the payment instrument among the $\mathrm{Y}$ generation in Surabaya is affected by the perceived usefulness. The $\mathrm{Y}$ generation perceives e-wallets as very useful transactional payments, as shown in Table 1, as a result, this perception makes the Y Generation switch from cash transactions to non-cash transactions. The finding of this study aligns with some previous studies by Camilleri [13]; Susanto et al. [15]; Abdullah et al. [10]; and Upadhyay and Jahanyan [25]. The positive influence of the path coefficient in Figure 1 shows the causal relationship between perceived usefulness $\left(\mathrm{X}_{1}\right)$ and behavioral intention to use (Z). It means that the higher the perception of usefulness, the higher the intention to use the e-wallet as the payment instruments among the $\mathrm{Y}$ generation in Surabaya. 
Table 7. Composite reliability

\begin{tabular}{lcc}
\hline \multicolumn{1}{c}{ Variable } & $\begin{array}{c}\text { Composite } \\
\text { reliability }\end{array}$ & $\begin{array}{c}\text { Cronbach's } \\
\text { Alpha }\end{array}$ \\
\hline Perceived usefulness & 0.890 & 0.852 \\
Perceived ease of use & 0.895 & 0.859 \\
Behavioral intention to use & 0.914 & 0.858 \\
Perceived usage & 0.894 & 0.822 \\
\hline
\end{tabular}

Table 8. R-Square

\begin{tabular}{lc}
\hline \multicolumn{1}{c}{ Variable } & R-Square \\
\hline Behavioral intention to use & 0.395 \\
Perceived usage & 0.388 \\
\hline
\end{tabular}

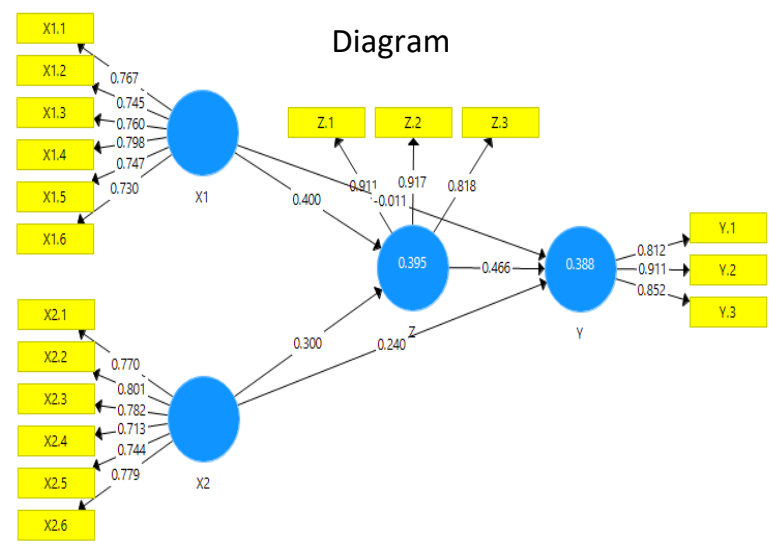

Figure 1. Output

The second hypothesis, which states perceived ease of use $\left(\mathrm{X}_{2}\right)$ having a positive and significant impact on behavioral intention to use $(\mathrm{Z})$, is accepted because the T-statistic shows the value of 3.514, greater than 1.96 . The perception of the ease to use is able to influence the intention of the $\mathrm{Y}$ generation to use e-wallet as the payment instrument. As shown in Table 2, the overall mean of perceived ease of use $\left(\mathrm{X}_{2}\right)$ is 4.378 , which indicates the $\mathrm{Y}$ generation having no difficulties in using e-wallet in transactional payments. The convenient payment process with e-wallet motivates the high intention to use among the $\mathrm{Y}$ generation in Surabaya. The hypothesis test result also shows the positive path coefficient of 0.300 , which means per- ceived ease of use having a positive impact on behavioral intention to use. The higher the perception of ease, the higher the intention to use e-wallets among the $\mathrm{Y}$ generation. The finding of this study is in accordance with other previous studies. Researches conducted by Davis [8]; Abdullah et al. [10]; Liu et al. [18]; Faham and Asghari [26]; Hansen et al. [27] found that perceived ease of use affects behavioral intention to use.

The third hypothesis, which states behavioral intention to use $(\mathrm{Z})$ having a positive and significant impact on perceived usage $(\mathrm{Y})$, is accepted because the $\mathrm{T}$ statistic value is 5.529, greater than 1.96. This proves that the high intention, shown in Table 3, can lead to actual usage. The Y generation in Surabaya makes actual payment with e-wallet mostly for the food and beverage transactions (81.5\%). Besides, the food and beverage businesses are very adaptive in implementing this technology by offering various cashbacks for the e-wallet users. The path coefficient value obtained from the original sample shows a positive value of 0.466 , meaning that behavior intention to use has a positive impact on perceived usage. The higher the intention to use e-wallets, the higher the actual usage of e-wallet as payment instruments among the Y generation. This study aligns with other previous researches conducted by Gupta and Arora [20] and Arif et al. [28], stating that there is a positive and direct influence between behavioral intention and actual usage.

The fourth hypothesis, which states behavioral intention to use ( $\mathrm{Z}$ ) acting as a mediator from perceived usefulness $\left(\mathrm{X}_{1}\right)$ to perceived usage $(\mathrm{Y})$, is accepted because the T-statistic shows the value of 3.069 , greater than 1.96. The results in Table 9 show that the direct path between perceived usefulness and perceived usage has a coefficient of -0.011 and a statistical value of 0.113 . This means that there is a negative and insignificant impact between perceived usefulness and perceived usage. The result is supported by a research by Hussein [29], stating that perceive useful-

Table 9. Resume of the hypothesis testing output

\begin{tabular}{lcccc}
\hline & $\begin{array}{c}\text { Original } \\
\text { sample }\end{array}$ & $\begin{array}{c}\text { Sample } \\
\text { mean }\end{array}$ & $\begin{array}{c}\text { Standard } \\
\text { deviation }\end{array}$ & T-statistic \\
\hline Path coefficients & -0.011 & -0.009 & 0.098 & 0.113 \\
Perceived usefulness $\rightarrow$ Perceived usage & 0.240 & 0.245 & 0.088 & 2.734 \\
Perceived ease of use $\rightarrow$ Perceived usage & 0.400 & 0.409 & 0.091 & 4.383 \\
Perceived usefulness $\rightarrow$ Behavioral intention to use & 0.300 & 0.296 & 0.085 & 3.514 \\
Perceived ease of use $\rightarrow$ Behavioral intention to use & 0.466 & 0.469 & 0.084 & 5.529 \\
Behavioral intention to use $\rightarrow$ Perceived usage & & & & \\
Indirect effects & 0.187 & 0.194 & 0.061 & 3.069 \\
Perceived usefulnes $\rightarrow$ Perceived usage & 0.140 & 0.137 & 0.043 & 3.238 \\
Perceived ease of use $\rightarrow$ Perceived usage & & & &
\end{tabular}


ness is not a significant predictor that influences individual to use a new technology. However, the indirect effect between perceived usefulness and perceived use through behavior intention to use shows a coefficient of 0.187 and a T-statistic value of 3.069, indicating a positive and significant impact through a mediating variable. This proves that behavioral intention to use acts as a mediating variable (full mediation).

The fifth hypothesis, which states behavioral intention to use $(\mathrm{Z})$ acting as a mediating variable from perceived ease of use $\left(\mathrm{X}_{2}\right)$ to perceived usage $(\mathrm{Y})$, is accepted because the T-statistic value is 3.238 , greater than 1.96. The finding of this study supports a research by Singh et al. [30], stating that ease of use has a significant effect on users' intentions and intention to use has a significant effect on recommendation to others to use mobile payment services. The indirect effect from perceived ease of use and perceived usage shows a coefficient of 0.140 , meanwhile the direct effect from perceived ease of use and perceived usage shows a coefficient of 0.240 . This result shows that the direct effect has a greater impact than the indirect effect. The behavioral intention to use only acts as a complementary partial mediation in the relation between perceived ease of use and perceived usage. The convenient use of e-wallet has already triggered the $\mathrm{Y}$ generation to use as payment instruments. The role of behavioral intention to use, such as cashbacks and discounts, does not bring a strong impact to the actual use of e-wallet for the $\mathrm{Y}$ generation in Surabaya.

\section{Conclusion}

This study is to investigate the actual use of e-wallet among the $\mathrm{Y}$ generation in Surabaya. The results show that perceived usefulness and perceived ease of use have positive and significant impacts on behavioral intention to use, and behavioral intention to use has a positive and significant impact on actual use. Perceived ease of use also has a positive and significant impact on perceived usage. However, perceived usefulness has a negative and insignificant impact on perceived usage. With the mediation of behavioral intention to use, perceived usefulness has a positive and significant impact on perceived usage of e-wallet as the payment instruments among the $\mathrm{Y}$ generation in Surabaya.

\section{Acknowledgment}

The authors would like to thank to Prof. Dr. Drs Eddy Madiono Sutanto, M.Sc. from Petra Christian University, Indonesia, for his assistance, support and encouragement to accomplish this research.

\section{References}

1. Bank Indonesia, 2018 Economic Report on Indonesia, 2019, retrieved from https://www.bi.go. $\mathrm{id} / \mathrm{en} /$ publication/annual-report/ economy/Pages/ LPI_2018-en.pdf

2. Bank Indonesia, Payment System Statistics, 2020, retrieved from www.bi.go.id/en/statistik/sistempembayaran/uang-elektronik/contents/jumlah \%20uang\%20elektronik\%20beredar(en).pdf

3. Morgan, J.P., E-commerce Payments Trends: Indonesia, 2019, retrieved from https://www. jpmorgan.com/merchantservices/insights/reports/indonesia.

4. Santoso, E., Millenial Finance, PT Gramedia, Jakarta, 2017.

5. Naim, M. F., and Lenka, U., Development and Retention of Generation Y Employees: A Conceptual Framework. Employee Relations, 40(2), 2018, pp. $433-455$.

6. Statistics of Surabaya City, Welfare Statistics of Surabaya Municipality 2019, 2019, Catalog number: 4101002.3578.

7. Cheng, F.M., Khim, C., and Thai, S., Consumer Adoption of E-Wallets: A Study of Millennials at the Institute of Foreign Languages, Cambodia, Proceedings of the 21st Asia-Pacific Conference on Global Business, Economics, Finance \& Social Sciences (AP18Taiwan Conference), TaipeiTaiwan, 2018, paper ID: W812

8. Davis, F. D., Perceived Usefulness, Perceived Ease of Use, and User Acceptance of Information Technology, Management Information Systems Quarterly, 13(3), 1989, pp. 319-340.

9. Nunes, A., Portela, F., and Santos, M. F., Improving Pervasive Decision Support System in Critical Care by using Technology Acceptance Model, Procedia Computer Science, 141, 2018, pp. 513-518.

10. Abdullah, F., Ward, R., and Ahmed, E., Investigating the Influence of the Most Commonly used External Variables of TAM on Students' Perceived Ease of Use (PEOU) and Perceived

Usefulness (PU) of e-portfolios, Computers in Human Behavior, 63, 2016, pp. 75-90.

11. Lok., C.K., Adoption of Smart Cardbased ePayment System for Retailing in Hongkong using an Extended Technology Acceptance Model, Business Marketing \& Purchasing, 23B, 2015, pp. 255-466.

12. Hubert, M., Blut, M., Brock, C., Zhang, R. W., Koch, V., and Riedl, R, The Influence of Acceptance and Adoption Drivers on Smart Home Usage, European Journal of Marketing, 2018, pp. 1073-1098. 
13. Camilleri, M.A., Exploring the Behavioral Intention to Use e-Government Services: Validating the Unified Theory of Acceptance and Use of Technology, International Conferences Internet Technologies \& Society 2019 and Sustainability, Technology and Education 2019, 2019, pp. 27-34.

14. Seetharaman, A., Kumar, K.N., Palaniappan, S. and Weber, G., Factors Influencing Behavioural Intention to Use the Mobile Wallet in Singapore, Journal of Applied Economics and Business Research, 7(2), 2017, pp. 116-136.

15. Susanto, A., Chang, Y., and Ha, Y., Determinants of Continuance Intention to Use the Smartphone Banking Services, Industrial Management \& Data Systems, 116(3), 2016, pp. 508-525.

16. Wu, J., Liu, L., and Huang, L. Consumer Acceptance of Mobile Payment Across Time: Antecedents and Moderating Role of Diffusion Stages, Industrial Management \& Data Systems, 117(8), 2017, pp. 1761-1776.

17. Susanto, T. D., and Aljoza, M.. Individual Acceptance of e-Government Services in a Developing Country: Dimensions of Perceived Usefulness and Perceived Ease of Use and the Importance of Trust and Social Influence, Procedia Computer Science, 72, 2015, pp. 622-629.

18. Liu, Z., Ben, S., and Zhang, R., Factors Affecting Consumers' Mobile Payment Behavioral Metaanalysis, Electric Commerce Research, Springer, 2019.

19. Davis, F. D., Bagozzi, R. P., and Warshaw, P. R., Use Acceptance of Computer Technology: A Comparison of Two Theoretical Models, Management Science, 35(8), 1989, pp. 982-1003.

20. Gupta, K., and Arora, N., Investigating Consumer Intention to Accept Mobile Payment Systems through Unified Theory of Acceptance Model, South Asian Journal of Business Studies, 9(1), 2020, pp. 88-114.

21. Hair, J.F., Risher, J.J., Sarstedt, M., and Ringle, C.M., When to Use and How to Report the Results of PLS-SEM, European Business Review, 31(1), 2019, pp. 2-24.
22. Kucukusta, D., Law, R., Besbes, A., and Legoherel, P., Re-examining Perceived Usefulness and Ease of Use in Online Booking, International Journal of Contemporary Hospitality Management, 27(2), 2015, pp. 185-198.

23. Taherdoost, H., Validity and Reliability of the Research Instrument; How to Test the Validation of a Questionnaire/Survey in a Research, International Journal of Academic Research in Management (IJARM), 5(3), 2016, pp. 28-36.

24. Franke, G., and Sarstedt, M., Heuristics versus Statistics in Discriminant Validity Testing: A Comparison of Four Procedures, Internet Research, 2019.

25. Upadhyay, P. and Jahanyan, S., Analyzing User Perspective on the Factors Affecting Use Intention of Mobile Based Transfer Payment, Internet Research, 26-(1), 2016, pp. 38-56.

26. Faham, E., and Asghari, H., Determinants of Behavioral Intention to Use e-Textbooks: A Study in Iran's Agricultural Sector, Computers and Electronics in Agriculture, 165, 2019, pp. 104935.

27. Hansen, J. M., Saridakis, G., and Benson, V., Risk, Trust, and the Interaction of Perceived Ease of Use and Behavioral Control in Predicting Consumers' Use of Social Media for Transactions, Computers in Human Behavior, 80, 2018, pp. 197-206.

28. Arif, M., Ameen, K., and Rafiq, M., Factors Affecting Student Use of Web-based Services, The Electronic Library, 36(3), 2018, pp. 518-534.

29. Hussein, Z., Leading to Intention: The Role of Attitude in Relation to Technology Acceptance Model in E-Learning, Procedia Computer Science, 105, 2017, pp. 159-164.

30. Singh, N., Sinha, N., and Liébana-Cabanillas, F. J., Determining Factors in the Adoption and Recommendation of Mobile Wallet Services in India: Analysis of the Effect of Innovativeness, Stress to Use and Social Influence, International Journal of Information Management, 50, 2020, pp. 191-205. 